\title{
PERANAN GURU BIMBINGAN DAN KONSELING DALAM PERENCANAAN KARIR SISWA KELAS XI DI SMA NEGERI 1 JARAI MELALUI MEDIA POHON KARIR
}

\author{
Novia Dumewa Putri \\ SMA NEGERI 1 JARAI
}

Email: putrinoviadumewa@gmail.com

\begin{abstract}
ABSTRAK
Tujuan penelitian adalah untuk mengetahui peranan guru bimbingan dan konseling dalam persiapan perencanaan karir siswa dan untuk mengatahui langkah-langkah yang akan dilakukan guru bimbingan dan konseling untuk persiapan kematangan karir siswa. Metode penelitian yang digunakan peneliti adalah deskriptif kualitatif menggunakan pendekatan fenomenologis. Subjek pada penelitian ini adalah guru BK dan siswa. Hasil penelitian ini, menunjukan bahwa bimbingan karir di SMA Negeri 1 jarai terhadap peningkatan pengetahuan karir peserta didik kelas XI IPS 1 di SMA Negeri 1 jarai sangat penting dan menentukan bagi pilihan karir peserta didik dengan media bantu berupa pohon karir yang dapat dibuat oleh siapapun dengan memanfaatkan bahan yang ada. Sebab, dengan ada nya layanan bimbingan karir, baik mengenai perguruan tinggi yang dapat meningkatkan pengetahuan pilihan karir peserta didik, yang semula tidak mengetahui sama sekali bimbingan kemudian mendapat kanbimbingan dari guru BK sehingga peserta didik memiliki kemantapan pilihan karir serta dunia kerja yang mereka impikan.
\end{abstract}

Kata Kunci : Peranan Guru Bimbingan dan Konseling, Media Layanan BK

\section{GUIDANCE AND COUNSELING TEACHER'S ROLE IN THE CAREER PLANNING IN SENIOR HIGH SCHOOL 10 STUDENTS THROUGH THE MEDIA OF THE CAREER TREE}

\begin{abstract}
The problem in this research is how the implementation of career planning for class Xl students at SMA Negeri 1 jarai through the media of career trees and what steps the Guidance and Counseling teacher should take to prepare for career planning for class Xl students. The research objective was to determine the role of guidance and counseling teachers in the preparation of student career planning and to determine the steps that the guidance and counseling teacher will take to prepare students for career maturity. The research method used by researchers is descriptive qualitative using a phenomenological approach. The subjects in this study were counseling teachers and students.The results of this study indicate that career guidance at SMA Negeri 1 jarai towards increasing the career knowledge of students in class XI IPS 1 at SMA Negeri 1 jarai is very important and determines the career choices of students with assistive media in the form of a career tree that can be made by anyone existing material. Because, with the existence of career guidance services, both regarding universities that can increase knowledge of the career choices of students, who initially did not
\end{abstract}


know the guidance at all, then received guidance from the counseling teacher so that students have the stability of their career choices and the world of work they dream of.

\section{Keywords: Role of Guidance and Counseling Teacher, BK Service Media}

\section{PENDAHULUAN}

Karir merupakan suatu hal yang ditempuh seseorang selama ia menjalani kehidupannya. Setiap individu yang akan berkarir memerlukan persiapan untuk merencanakan karir yang di inginkan, salah satunya peserta didik (remaja) yang yang tengah berada pada masa akhir karir sekolah, sehingga perlu merencanakan karir dimasa yang akan datang. Perencanaan karir adalah sebagian proses yang dilalui sebelum pemilihan karir. Sering kali terjadi kesalahaan dalam mengambil pilihan dikarenakan beberapa faktor, baik faktor internal maupun ekstrenal. salah satunya adalah minim nya informasi yang mereka peroleh tentang studi lanjut. Hal ini sering terjadi pada siswa SMA yang akan menentukan recana karirnya untuk memperoleh masa depan yang cemeralang.

\section{LANDASAN TEORI}

Menurut Soejono Suekanto, peranan guru BK adalah tenaga professional yang memperoleh pendidikan khusus diperguruan tinggi dan mencurahkan seluruh waktunya pada layananan bimbingan. Guru BK memberikan layananlayanan bimbingan kepada para siswa dan menjadi konsultan bagi staf sekolah danorang tua (Winkel \& Sri Hastuti,2012). Peranan - peranan guru BK berdasarkan teori diatas adalah tindakan yang dilakukan oleh orang yang mempunyai kedudukan atau seorang tenaga professional dalam memberikan layanan-layanan bimbingan kepada para siswa.

Peran guru sebagai pelaksana layanan Bimbingan dan Konseling dalam membangun sikap displin siswa yaitu sebagai pembimbing, dan kolaborator saja, sedangkan peran guru sebagai mediator. Perencanan karir merupakan kata yang sering diungkap seseorang yang berkaitan dengan pekerjaan . Homby ( Walginto, 2010 : 201) menyatakan bahwa " karir merupakan pekerjaan profesi ",

Peraturan pemerintah yang menyatakan bahwa standar kompetensi lulusan pada satuan pendidikan menengah umum bertujuan meningkatkan kecerdasaan, 
pengetahuan, akhlak serta keterampilan untuk menjadi mandiri dan bias mengkuti pendidikan lebih lanjut. Hal ini menunjukan bahwa siswa SMA harus mempersiapkan diri untuk karirnya kedepan yang sesuai dengan minta serta bakatnya. Karena masih banyak siswa yang bingung menentukan studi lanjutnya sehingga berdampak tidak baik pada perencaan karirnya. Sering terjadinya kesalahan dalam pemilihan atau perencanan karir di karenakakan kurangnya informasi tentang studi lanjut.

Kurikulum SMA dirancang untuk mempersiapkan siswa melanjutkan pendidikan berikutnya. Kurikulum yang di pakar atau dipakai di SMA yaitu kurikulum 2013 ( K-13) hal ini diatur dalam permendikbut No.160 Tahun 2014 tentang pemberlakuan kurikulum tahun 2006 dan kurikulum 2013 pada tahun 2019 /2020 maka semua sekolah di Indonesia memberlakukan K-13. Setelah siswa melewati beberapa tahap kelulusan pendidikan di tingkat SMA, selayaknya ia melanjutkan ke jenjang perguruan tinggi. Melanjutkan pendidikan di perguruan tinggi sangatlah penting bagi siswa SMA mengenali potensi dan kemampuan yang dimiliki. Namun pengambilan keputusan menentukan pilihan keperguan tinggi tidaklah mudah. Perjalanan dalam mengambil keputusan memilih keperguruan tinggi ternyata diperlukan pertimbangan yang matang. Memilih perguruan tinggi bagi siswa sma sederajat, sama dengan memilih masa depan.

Masalah yang terjadi pada peserta didik kelas XI di SMA Negeri 1 Jarai dalam perencanaan karirnya adalah terjadinya kesenjagan dalam menentukan pilihan karir seperti menetukan pendidikan lanjutan di sekolah tersebut terdapat beberapa sisswa yang yang belum bisa menentukan perencanan karir. Maka dari itu guru BK di SMA Negeri 1 Jarai melakukan layananan informasi perencanaan karir dengan media pohon karir, untuk mememudahkan siswa memahami dan merencanakan karir. Kondisi seperti ini banyak dialami siswa kelas XI SMA Negeri 1 Jarai. Banyak siswa yang masih bingung tentang studi lanjut dan tidak mengerti akan arah karir meraka. Maka dari itu guru bimbingan dan konseling di sekolah memiliki peranan dalam permasalahan dalam membantu siswa dalam mempersiapkan perencanaan karir serta menambah pemahamaan baru dalam kematangan karir untuk bisa mengapai cita-cita masa depan mereka. 
Menurut Peraturan Menteri Pendidikan Nasional No. 27 Tahun 2007 tentang Standar Kualifikasi Akademik dan kompentesi konselor yaitu bagian Kompentesi professional. Peranan guru Bimbingan dan Konseling disini ialah untuk dapat mengimplikasikan program-program yang ada dalam bimbingan dan koseling yang komprehensif terdapat empat kompetensi yang diharapkan yaitu sebagai berikut :

1. Melaksanakan program bimbingan dan konseling.

2. Melaksanakan pendekatan kolaboratif dalam pelayanan bimbingan dan konseling.

3. Memfasilitasi perkembangan akademik, karier, personal, dan sosial konseling.

4. Mengelola sarana dan biaya program bimbingan dan konseling

Sebagai guru bimbingan dan koseling dapat membatu mereka melalui layananan informasi dan dapat juga kita terapkan memalalui media yang ada dalam bimbingan dan konseling salah satunya ialah media pohon karir disini siswa dapat melihat dengan jelas apa yang dimaksud dengan karir serta potensi yang meraka miliki itu bisa menuju karir yang mana. Serta dari jurusan yang mereka ambil itu nantinya bias masuk dimana serta melanjutkan studi lanjut ke universitas mana dengan mengabil jurusan apa kita ambil contoh jurusan IPA nantinya mereka bisa mengambil jurusan, kedokteran, bidan, dan lain sebagianya.

Berdasarkan hasil penelitian di sekolah peneliti tertarik untuk menganalisis perencanaan karir di sekolah, meningkatkan pelayanan informasi karir melalui media dengan judul penelitian "Peranan guru bimbingan dan konseling dalam perencanaan karir siswa kelas Xl di SMA NEGERI 1 JARAI melalui media pohon karir “

\section{METODE PENELITIAN}

Metode penelitian adalah penelitian kualitatif lapangan (field Research). Penelitian kualitatif merupakan penelitian yang menghasilkan data deskriptif berupa kata-kata tertulis atau lisan dari orang-orang dan perilaku yang dapat diamati dan diarahkan pada latar alamiah dan individu tersebut secara menyeluruh. 
Tempat pelaksanaan penelitian akan dilakukan di SMA Negeri 1 Jarai.Jl Mayor Ruslan, 51519, Karang Tanding,Kabupaten Lahat, Sumatra Selatan 31591. Penelitian akan di lakukan pada bulan juli 2020 sampai dengan selesai . mengunakan instrumen wawancara.

Objek dalam penelitian ini adalah peranan guru bimbingan dan konseling dalam meningkatkan pemahaman dan perencanaan karir siswa kelas XI di SMA Negeri 1 Jarai melalui media pohon karier.

Subjek dalam penelitian ini adalah guru bimbingan dan konseling di SMA Negeri 1 Jarai. guru bimbingan dan konseling di SMA Negeri 1 Jarai untuk menunjang informasi tambahan yang di butuhkan dalam penelitian ini, inforrman tambahan itu yaitu, siswa di SMA Negeri 1 Jarai.

\section{HASIL DAN PEMBAHASAN}

\section{HASIL PENELITIAN}

Analisis data pada tahap penelitian ini, peneliti menggunakan model Miles dan Huberman yang bertujuan dalam mengemukakan hasil dari analisis data yang telah diperoleh peneliti mengenai peranan guru Bimbimgan dan Konseling dalam perencanan karir siswa kelas XI melalui media pohon karir yang didapatkan ketika peneliti melakukan observasi dan wawancara di SMA Negeri 1 Jarai yang dilakukan pada tanggal 14-18 juli 2020 secara mendalam dan kebenarannya dapat terjamin dan dipercaya. Adapun data yang akan di analisis dengan langkahlangkah menurut Miles dan Huberman sebagai berikut antara lain :

1. Reduksi Data

Berdasarkan hasil observasi dan wawancara dengan pihak guru bimbingan dan koseling, pada tahapan ini peneliti telah memfokuskan apa saja yang menjadi kendala akan perencanaan karir siswa permasalahan penelitian mengenai peranan guru bimbingan dan koseling dalam perencanaan karir siswa kelas XI di SMA Negeri 1 Jarai yang dapat dilihat dari kegiatan pemberian layanan Bimbingan dan Konseling yang diberikan guru Pembimbing kepada siswa serta media yang digunakan yang dilakukan oleh guru bimbingan dan konseling untuk mearik minat siswa SMA Negeri 1 Jarai. 


\section{Penyajian Data}

Tahapan selanjutnya dalam analisis data yaitu peneliti melakukan penyajian data dalam bentuk uraian singkat. Berdasarkan dari hasil observasi dan wawancara yang dilakukan peneliti secara terjun langsung ke lapangan sehingga diperolehlah gambaran peranan guru bimbingan dan konseling dalam perecanaan karir siswa kelas XI di SMA 1 Jarai .melalui mediapohon karir. peranan Guru Bimbingan dan Konseling serta media yang digunakan yang sudah direncanakan/dbuat oleh Guru Bimbingan dan Konseling sangat mempengaruhi minat serta perencanaan karir siswa dalam mengikuti kegiatan perencanaan karir, sehingga Guru Bimbingan dan Konseling dituntut untuk dapat meningkatkan pembuatan media karir lainya agar dapat membuat kegiata perecanaan karir selalu aktif berjalan dan diminati oleh seluruh siswa.

\section{Penarikan Data/ kesimpulan}

Setelah adanya tahapan reduksi dan penyajian data maka tahapan selanjutnya yang dapat peneliti lakukan yaitu penarikan kesimpulan dari analisis data mengenai Gambaran peranan guru bimbingan dan konseling dalam perencanaan karir siswa kelas XI di SMA Negeri 1 Jarai melalui media pohon karir, hal ini dikarenakan di sekolah guru bimbingan dan konseling telah melakukan layanan perencanaan karir terhadap siswa walaupun belum terlalau efektif akan tetapi pihak guru bimbingan dan konseling. Akan selalu menambah pengetahuan- pengetahuan baru untuk meningkat perecanaan karir ini karena sangat mendukung perencanan siswa baik untuk memasuki dunia perkuliahan maupun pekerjaan selalu menyiapkan media- media baru serta menambah informasi yang baru untuk menambah pengetahuan mereka kedepan untuk dapat dibagikan ilmunya untuk siswa kedepannya.

\section{PEMBAHASAN}

Berdasarkan deskripsi proses dan hasil wawancara peneliti dengan guru BK SMA Negeri 1 Jarai mealui media pohon karir maka layanan bimbingan karir bertujuan untuk memantapkan pilihan karir peserta didik setelah lulus dari SLTA. Pengetahuan karir mengarah pada pengenalan karir secara menyeluruh, yang 
prosesnya diawali dengan pengenalan potensi diri, memahami lapangan perguruan tinggi yang sebenarnya, merencanakan sampai dengan menentukan pilihan karir yang tepat.

Yean \& Yahya (2013: 25) menjelaskan bahwa perencanaan karir adalah kegiatan yang membuat seseorang individu untuk bertanggung jawab dan mengembangkan karirnya. Usaha mengembangkan karir tersebut dapat diwujudkan dalam sebuah tindakan nyata. Tindakan yang dilakukan secara sadar dan disengaja untuk memilih dan memutuskan tempat tinggal dan pekerjaan demi mencapai kehidupan yang bahagia dengan memperhatikan peluang dan berbagai alternatif pilihan (Alberta, 2007: 4).

Bedasarkan hasil wawancara dengan guru BK, layanan bimbingan karir yang diberikan kepada peserta didik dengan mengunakan media pohon karir dapat mematangkan pilihan karir peserta didik agar pesrta tidak merasa jenuh ataupun bosan. Dalam mengembangkan pencapaian pengetahuan karir peserta didik, ada empat hal yang dilakukan guru BK.

Menurut teori Donlad. E. Super, Pertama, bimbingan mengenai pengetahuan diri peserta didik. Peserta didik harus menjadi idividu yang potensial dengan memahami bakatnya sendiri, kecakapan dan kemampuannya, konsep diri dan penghargaan diri, kepribadian, kemampuan akademik, pengalaman belajar dan perguruan tinggi, minat, tingkat harapan, hasil belajar, dan sebagainya.Semua karakteristik ini seharusnya sesuai dengan pilihan karir mereka.

Kedua, bimbingan studi, pekerjaan dan karir.Peserta didik tidak hanya membutuhkan bimbingan mengenai diri mereka, tetapi juga tentang lingkungan dimana mereka tinggal. Mereka juga membutuhkan bimbingan mengenai pilihan pendidikan yang lain (jenjang pendidikan), pilihan professional/pekerjaan (jenjang karir), dan pilihan karir (jenjang sosial tenagaperguruan tinggi). Mereka membutuhkan bimbingan tersebut sebagai bahan pertimbangan.

Ketiga, proses dalam menentukan keputusan karir. Melalui pengetahuan mengenai diri, pendidikan dan pengembangan profesional, peserta didikakan menentukan keputusan karir yang tepat. Mereka seharusnya dipersiapkan dalam menentukan keputusan karir melalui pertimbangan berbagai aspek tersebut. 
Keempat, perencanaan karir.Peserta didik seharusnya dipersiapkan untuk menentukan perencanaan karir dengan berpedoman pada karakteristik pribadi, pengalaman studi dan pengalaman perguruan tinggi. Perencanaan karir akan membuat peserta didik teguh pendirian dalam pendidikan dan karir jadi, terdapat hubungan antara bimbingan yang diberikan dengan dampak dari infomasi tersebut.

Hasil wawancara dengan peserta didik dalam wawancara mengenai bimbingan karir dalam Peningkatan Pengetahuan karir Peserta Didik melalui media pohon karir jauh lebih baik dari pada sekedar pemilihan perguruan tinggi, karena akan melibatkan kemampuan individu baik dalam dalam membuat keputusan karir maupun aktivitas perencanaan karir. Pengetahuan karir mengarah pada pengenalan karir secara menyeluruh, diawali dengan pengenalan potensi diri, memahami lapangan perguruan tinggi yang sebenarnya, merencanakan atau memilih perkerjaan yang baik sampai dengan menentukan pilihan karir yang tepat.

\section{KESIMPULAN}

Dari hasil pembahasan diperoleh kesimpulan bahwa :

1. Proses layanan bimbingan karir yang dilakukan guru BK terhadap peserta didik kelas XI SMA Negeri 1 Jarai dimulai dari penyiapan materi layanan bimbingan karir dari berbagai sumber. Ada dua materi yang disiapkan oleh guru BK, yaitu materi yang berhubungan dengan bimbingan perguruan tinggi. Materi pertama berhubungan dengan profil perguruan tinggi terkemuka baik negeri maupun swasta, keunggulan dan kelebihan perguruan tinggi satu dengan yang lain, tenaga pengajar. Materi perguruan tinggi yaitu bimbingan seputar dunia perkerjaan mealalui media pohon karir.

2. Bimbingan karir di SMA Negeri 1 Jarai terhadap peningkatan pengetahuan karir peserta didik kelas XI IPS 1 di SMA Negeri 1 Jarai sangat penting dan menentukan bagi pilihan karir peserta didik dengan media bantu berupa pohon karir yang dapat dibuat oleh siapapun dengan memanfaatkan bahan yang ada. Sebab, dengan adanya layanan bimbingan karir, baik mengenai perguruan tinggi yang dapat meningkatkan pengetahuan pilihan karir peserta 
didik, yang semula tidak mengetahui sama sekali bimbingan kemudian mendapatkan bimbingan dari guru BK sehingga peserta didik memiliki kemantapan pilihan karir serta dunia kerja yang mereka impikan.

\section{DAFTAR PUSTAKA}

Daryanto. 2015. Bimbingan dan Konseling. Malang : Gava Media

Donald E. Super, Psiologi karir, terj. Ahmad Hawani, Pustska Pelajar , Yogyakarta , 2006

Dr. Hartono, M.Si. 2018. Bimbingan Karier . Jakarta; prenadamedia Group.

M.Ferdiansyah. 2015. Dasar Penelitian Kualitatif . Bogor : Herya Media

Resti Susanti. 2019. Pelaksanaan Bimbingan Karier Untuk Memperisiapkan Siswa Memasuki Perguruan Tinggi di SMA Se-Jakarta Utara. Resti Susanti. Vol.4 : Garuda ristekdikti.

Richma Hidayati. 2015. Layanan informasi membantu peserta didik dalam meningkatkan pemahamaan karir. Richma Hidayati. Vol.1 : Garuda Ristekdikti

Robert Nathan \& Linda. 2012 Konseling Karier. Yogyakarta : Pustaka Pelajar

Sugiyono. 2017. Metode Penelitian Kusntitatif, Kualitatif dan R\&D. Bandung : Alfabeta 